Електронне наукове фахове видання "Ефективна економіка" включено до переліку наукових фахових видань України з питань економіки (Категорія «Б», Наказ Міністерства освіти і науки України від 11.07.2019 № 975) www. economy.nayka.com.ua | № 4, 2021 | 29.04.2021 p.

DOI: $10.32702 / 2307-2105-2021.4 .99$

UDC 339.9

\author{
O. Pshyk-Kovalska
}

PhD in Economics, Associate Professor,

Associate Professor of the Department of Management and International Business,

National University "Lviv Polytechnic", Lviv

ORCID ID: 0000-0002-6017-7444

V. Ivaniutina

Student, National University "Lviv Polytechnic", Lviv

ORCID ID: 0000-0002-1654-3478

\title{
IMPACT OF COVID - 19 ON THE ECONOMIES OF UKRAINE AND GERMANY
}

\author{
О. О. Пшик-Ковальська, \\ к. е. н., дочент, доцент кафедри менеджменту та міжнародного підприємництва, \\ Національний університет «Львівська політехніка», Львів, Україна \\ В. Ю. Іванютіна, \\ студентка, Національний університет «Львівська політехніка», Львів, Україна
}

\section{ВПЛИВ COVID - 19 НА ЕКОНОМІКУ УКРАЇНИ ТА НІМЕЧЧИНИ}

The article provides the analysis and a brief description of the positive and negative impact of the COVID19 pandemic on some global sectors of the economy. The following changes in the main macroeconomic indicators of Ukraine and Germany due to the outbreak of the epidemic are under investigation: GDP, external debt, inflation and unemployment, exports and imports of goods and services, foreign trade, and foreign trade balance. The article highlights the fact that due to the crisis caused by the COVID-19 pandemic, Ukraine's industry in 2020 was on the verge of extinction. It has been established that the economic recession, declining purchasing power and changes in the behavior of citizens, lack of state aid (or its inefficiency) by the government have led to a reduction in production, or even the shutdown of entire sectors of the national economy. During the crisis, the Ukrainian government introduced a strict regulatory policy that created obstacles to the activities of private enterprises, which reduced their profitability and liquidity. The article emphasizes that first of all the consequences of the COVID-19 pandemic significantly affected small and medium enterprises. Large corporations were forced to cut staff, send employees on unpaid leave, reduce wages and working hours. It is noted that among the EU countries, Germany was one of the first to suffer the negative effects of the pandemic, which was due to the high level of openness of the economy, respectively, dependence on exports and imports of goods and services. Tough measures taken by the German government to fight the COVID-19 pandemic (quarantine for citizens) have significantly worsened the situation in the economy. To overcome the effects of the crisis, the German government has developed and implemented a large-scale program of support to businesses. The article presents the measures implemented by the governments of Ukraine and Germany to overcome the COVID-19 pandemic and stabilize the economic situation in the countries. Certain actions that the Government of Ukraine should implement in order to overcome the negative consequences of the coronavirus epidemic are as well highlighted.

В статті проаналізовано та наведено коротку характеристику позитивного і негативного впливу пандемії COVID-19 на окремі світові галузі економіки. Досліджено зміни головних 
макроекономічних показників України та Німеччини внаслідок спалаху епідемії, а саме: ВВП, зовнішнього боргу, рівня інфлячії та безробіття, обсягів експорту та імпорту товарів і послугів, зовнішньоторговельного обороту, а також сальдо зовнішньої торгівлі. В статті висвітлено, що у зв'язку з кризовою ситуаџією, спричиненою пандемією COVID-19, промисловість України в 2020 р. знаходилася на межі існування. Встановлено, щзо рецесія економіки, падіння купівельної спроможності та видозміна поводження громадян, відсутність державної допомоги (або ії неефективність) з боку уряду призвели до скорочення обсягів виробництва, або навіть зупинки иілих галузей начіонального господарства. В умовах кризи украйнський уряд запровадив сувору регуляторну політику, яка створила перешкоди для діяльності приватних підприємств, щяо знизило їх рентабельність та ліквідність. В статті заакиентовано, щуо насамперед наслідки пандеміі COVID-19 значною мірою вплинули на малі та середні підприємства. Великі корпораџії були змушені скорочувати штат, відправляти працівників у безкоштовні відпустки, зменшувати заробітну платню та робочі години. Зазначено, щуо серед країн Євросоюзу, Німеччина однією $з$ перших зазнала негативні наслідки пандемії, щз було обумовлено високим рівнем відкритості економіки, відповідно, залежністю від експорту та імпорту товарів і послуг. Жорсткі заходи уряду ФРН, які були впроваджені для подолання пандемії COVID-19 (введення карантину для громадян) істотно погіриили ситуацію в економіці. Для подолання наслідків кризи урядом Німеччини було розроблено $i$ впроваджено масштабну програму допомоги суб'єктам господарювання. В статті наведено заходи, щзо впроваджували уряди Украӥни та Німеччини щодо подолання пандемії COVID-19 та стабілізачії економічної ситуачії в країнах. Виокремлено певні дії, які уряду Украӥни доцільно реалізувати задля подолання негативних наслідків епідемії коронавірусу.

Keywords: economic crisis; COVID-19 pandemic; international economies; international economic relations between Ukraine and Germany; recession.

Ключові слова: економічна криза; пандемія COVID-19; міжнародна економіка; міжнародні економічні відносини Украӥни та Німеччини; рецесія.

Problem statement. The COVID-19 pandemic contributed to the adoption, at the state level, of measures aimed at introducing quarantine restrictions, namely: the closure of state borders, the cessation of transport connection and the functioning of a large number of enterprises, as well as the introduction of other restrictive measures for business. All this has negatively impacted the world economy.

The economies of all countries will feel the effects of reduced world production, disruption of trade chains, reduced investments. Declining consumer demand in the European Union and the United States will negatively impact import from developing countries. In the current conditions, the quarantine measures in China had a great impact on the world economy, as the production facilities of many industrial and innovative companies of the world are located on the territory of this country. The closure of plants and factories, as well as declining demand for Chinese products, had a negative impact on the profits of such companies.

The complete or partial shutdown of a number of enterprises will also have a negative impact on the global labor market - about $80 \%$ ( 3 billion) of the working population of the world suffered from the COVID-19 pandemic [1]. The most exposed to the risk of reduction, are workers in such industries as: arts and entertainment, transportation services, hospitality business, real estate market, industrial production. While those who are employed in education, health care, agriculture, and public service will be less affected by the negative trends.

Governments around the world are committed to creating and implementing economic programs aimed at mitigating the effects of the COVID-19 pandemic and stabilizing the economy. Given this situation in the world, the urgent issue is the search for macroeconomic instruments that would help reduce the impact of the COVID-19 pandemic on the world economy and the economy of Ukraine in particular.

Analysis of recent research and publications. Owners and top managers of companies in key sectors of the Ukrainian economy, government officials, journalists, economic and social experts, physicians took an active part in the discussion of this topic. In particular, M. Repko, V. Kravchuk, G. Chizhikov, TB Peters, A. Karakuts, D. Denkov, I. Tynny, M. Bogdanov, R. Romanchuk and O. Davymuka and others. Foreign scientists, namely L. Shade, KF Burrig, K. Puschel, A. Tsankov, D. Horst, H. Radbruch, F. Heppner, K. Drosten, M. Sturmer, also focused their attention on this problem. K. Neil and others. [2]. In particular, K. Boyarinov, V. Dergachev, M. Kravchenko and K. Kopishinska analyzed the forecasts of the impact of the coronavirus pandemic on the economy of Ukraine and neighboring countries and studied the specifics of anti-crisis measures to overcome the spread of coronavirus in foreign countries [3]. In general, the topic of the impact of COVID-19 on the economies of the world is only gaining popularity in domestic and foreign studies. In current conditions, the issue of creating of the macroeconomic instruments to overcome the negative consequences of the pandemic, as well as the development of international economic relations between countries has become especially topical.

Research objective. The aim of the study is to conduct the comparative analysis of macroeconomic instruments aimed at stabilizing the economic situation, international economic relations in Ukraine and Germany during the 
COVID-19 pandemic.

Presentation of research. The current state shows that the COVID-19 pandemic has affected all sectors of the world economy (tab. 1).

Table 1. Analysis of the impact of the COVID-19 pandemic on particular world economic industries

\begin{tabular}{|c|c|c|}
\hline № & $\begin{array}{l}\text { Name of } \\
\text { industry }\end{array}$ & Characteristics \\
\hline 1 & 2 & 3 \\
\hline \multicolumn{3}{|r|}{ Negative impact } \\
\hline 1 & Tourism & $\begin{array}{l}\text { One of the most affected industries due to restrictions imposed on movement between } \\
\text { countries. The World Travel and Tourism Council estimates that COVID-19 could cause } \\
\text { the loss of about } 50 \text { million jobs in the industry [2]. In an attempt to compensate for the } \\
\text { losses, a number of travel companies have announced the start of online booking of tours } \\
\text { for the beginning of } 2021 \text {. However, prices for them are significantly higher than in } 2019 \text {, } \\
\text { which, accordingly, has a negative impact on the already low demand for these services. }\end{array}$ \\
\hline 2 & $\begin{array}{c}\text { Transportation } \\
\text { services }\end{array}$ & $\begin{array}{l}\text { Significant losses are experienced by airlines whose demand for services has dropped to } \\
\text { zero in the quarantine situaiton. The expected reduction in revenues due to restrictions on } \\
\text { transport and passenger traffic, according to the International Air Transport Association, } \\
\text { could reach } 252 \text { billion USD, which is } 44 \% \text { less than in } 2019 \text { [3]. In order to minimize } \\
\text { losses, airlines introduce a flexible policy to change the date of booking tickets, vouchers, } \\
\text { loans or cancel the reservation. Carriers are also reducing the size of the fleet and using } \\
\text { aircraft that are designed for a small number of passengers. } \\
\text { Crisis phenomena have been noted in the automotive industry as well, which is primarily } \\
\text { due to the fact that about } 80 \% \text { of world supply chains in this industry, one way or } \\
\text { another, are associated with China. The main reasons for the decrease in revenues in this } \\
\text { industry are: failures in the supply of spare parts from China, production disruptions in } \\
\text { Europe, the closure of car assembly plants in the United States. }\end{array}$ \\
\hline 3 & Food & $\begin{array}{l}\text { Agricultural producers may also suffer losses, given the sector's strong dependence on } \\
\text { imported plant protection equipment (ie fertilizers and pesticides). Unstable market } \\
\text { conditions have caused some negative impact on a number of supply chains in the field of } \\
\text { agricultural exports. } \\
\text { Reducing availability of labor remains a concern for the food and agricultural businesses, } \\
\text { especially in the horticulture, and food industries. }\end{array}$ \\
\hline 4 & Oil & $\begin{array}{l}\text { About } 60 \% \text { of oil consumption is related to human mobility, respectively, quarantine } \\
\text { measures have significantly affected demand in this area. The main loss is a significant } \\
\text { decline in the capitalization of a number of global oil companies due to falling demand } \\
\text { for oil due to transport restrictions and reduced energy consumption. Oil prices have } \\
\text { reached the lowest level in } 17 \text { years, as a result - its production may become unprofitable } \\
\text { for some companies. }\end{array}$ \\
\hline \multicolumn{3}{|r|}{ Positive impact } \\
\hline 5 & E-Commerce & $\begin{array}{l}\text { Under quarantine and lockdown conditions, people spend most of their time at home, } \\
\text { which has had a corresponding impact on consumer behavior - online shopping became a } \\
\text { preference. }\end{array}$ \\
\hline 6 & Pharmaceutical & $\begin{array}{l}\text { The efforts of the world's leading pharmaceutical companies are focused primarily on the } \\
\text { development of a vaccine against COVID-19. Another important aspect of their activities } \\
\text { is the timely supply of the necessary quantities of medicines and protective equipment, } \\
\text { which are in great demand in the context of a coronavirus pandemic. }\end{array}$ \\
\hline 7 & $\begin{array}{l}\text { IT } \\
\text { (communication } \\
\text { technologies; } \\
\text { entertainment } \\
\text { and game } \\
\text { services) }\end{array}$ & $\begin{array}{l}\text { Most of the office workers are forced to work remotely, thus the online conferencing } \\
\text { services have become very popular. In addition to sales growth, there is also an increase } \\
\text { in the capitalization of Zoom, Webex (Cisco), Skype (Microsoft) in this industry. } \\
\text { The inability of people to spend leisure time in cinemas and malls encourages more and } \\
\text { more to use similar online services at home. Examples of successful companies are } \\
\text { Netflix, Amazon Prime Video, Disney +, Steam, MEGOGO. }\end{array}$ \\
\hline
\end{tabular}

The presented data shows that the decline in economic activity has hit tourism, passenger air transportation and food services the most significantly. According to the IMF, Ukraine's GDP fell to about $9.1 \%$ in 2020 compared to 2019 and is expected to grow to $3 \%$ in 2021 and $3.2 \%$ in 2022, given the recovery of the world economy after the pandemic [4].

It is worth mentioning that the coronavirus pandemic has reduced the economic potential not only of developing countries but also of economically developed countries such as Germany, England and the United States. Germany is the largest economic power in Europe and the fourth largest in the world. However, due to the outbreak of the COVID-19 pandemic, the country's economy, according to IMF estimates, shrank by $9.7 \%$ in 2020 [4].

Let us analyze the impact of the COVID-19 pandemic on the macroeconomic indicators of Ukraine and Germany for the period of $2018-2020$ (tab. 2). 
Table 2. Macroeconomic indicators of Ukraine and Germany for the period of 2018 - 2020 (formed on the basis of 5 )

\begin{tabular}{|c|c|c|c|c|c|c|c|c|c|c|c|}
\hline \multirow[b]{2}{*}{ № } & \multirow[b]{2}{*}{ Indicators } & \multicolumn{3}{|c|}{ Ukraine } & \multicolumn{2}{|c|}{$\begin{array}{c}\text { Deviation } \\
2019 / 2020 \\
\end{array}$} & \multicolumn{3}{|c|}{ Germany } & \multicolumn{2}{|c|}{$\begin{array}{l}\text { Deviation } \\
\text { 2019/2020 }\end{array}$} \\
\hline & & 2018 & 2019 & 2020 & $\begin{array}{c}\text { Absol } \\
\text { ute } \\
\text { units }\end{array}$ & $\begin{array}{l}\text { Relati } \\
\text { ve } \\
\text { Units. }\end{array}$ & 2018 & 2019 & 2020 & $\begin{array}{c}\text { Absol } \\
\text { ute } \\
\text { units }\end{array}$ & $\begin{array}{l}\text { Relati } \\
\text { ve } \\
\text { Units. }\end{array}$ \\
\hline 1. & GDP, billion dollars USA & 130,93 & 154,69 & 142,25 & $-12,44$ & $-8,04$ & 3965,57 & 3861,55 & 3780,55 & -81 & $-2,09$ \\
\hline 2. & $\begin{array}{l}\text { External debt, billion } \\
\text { dollars USA }\end{array}$ & 114,449 & 117,409 & 122,799 & 5,39 & 4,59 & 4,867 & 4,974 & 5,534 & 0,56 & 11,25 \\
\hline 3. & Inflation rate, \% & 10,9 & 7,9 & 3,2 & $-4,7$ & $-59,49$ & 2,0 & 1,3 & 0,5 & $-0,8$ & $-61,53$ \\
\hline 4. & Unemployment rate, \% & 9,0 & 8,5 & 11,0 & 2,5 & 29,41 & 5,2 & 5 & 6,4 & 1,4 & 28 \\
\hline 5. & $\begin{array}{l}\text { Exports of goods and } \\
\text { services, billion dollars } \\
\text { USA }\end{array}$ & 59,2 & 63,6 & 60,6 & -3 & $-4,71$ & 1,878 & 1,811 & 1,617 & $-0,19$ & $-10,71$ \\
\hline 6. & $\begin{array}{l}\text { Imports of goods and } \\
\text { services, billion dollars } \\
\text { USA }\end{array}$ & 70,6 & 76,1 & 62,3 & $-13,8$ & $-18,13$ & 1,634 & 1,586 & 1,417 & $-0,16$ & $-10,65$ \\
\hline 7. & $\begin{array}{l}\text { Foreign trade turnover, } \\
\text { billion dollars USA }\end{array}$ & 129,8 & 139,7 & 122,9 & $-16,8$ & $-12,02$ & 3,512 & 3,397 & 3,034 & $-0,36$ & $-10,68$ \\
\hline 8. & $\begin{array}{l}\text { Foreign trade balance, } \\
\text { billion dollars USA }\end{array}$ & $-11,4$ & $-12,5$ & $-1,7$ & 10,8 & $-86,4$ & -244 & -225 & -200 & 25 & $-11,11$ \\
\hline
\end{tabular}

Ukraine's GDP decline due to COVID-19 has increased the budget deficit, reaching 4.5\% of GDP in 2020 (from $1.8 \%$ in 2019) and projected to be $3.8 \%$ of GDP in 2021 and -3\% of GDP in 2022 [4]. Ukraine's public debt has increased significantly from $50.1 \%$ of GDP in 2019 to $65.7 \%$ of GDP in 2020 and is expected to remain high in 2021 (64.3\% of GDP) and 2022 (61, 8\% of GDP) [4]. Unemployment in Ukraine decreased until 2019, but due to the negative economic impact of COVID-19 it increased to $11 \%$ in 2020 and is projected to remain high in $2021(9.6 \%)$ and $2022(9 \%)$ [4].

In June 2020, the IMF approved a \$ 5 billion support package to help Ukraine cope with the COVID-19 pandemic. The policy under the new agreement focuses on four priorities: mitigating the economic consequences of the crisis; ensuring the permanent independence of the central bank and a flexible exchange rate; ensuring financial stability when reimbursing the costs of bank loans; and moving forward with key management and anti-corruption measures to preserve and enhance recent achievements [4]. The budget priorities for 2021 include health care, the purchase of vaccines from COVID-19, raising the minimum wage and pensions, education and agriculture.

An analysis of Ukraine's foreign trade shows that it is the world's fifth largest exporter of grain and one of the main exporters of iron and steel [4, 6]. In 2019, the main export goods were grain (19.32\% of exports), cast iron and steel (17.52\%), fats and oils (9.49\%), electrical equipment and fuel [4]. The main imported goods were fuel (20.06\% of imports), machinery (10.97\%), electrical equipment (10.97\%), vehicles (9.55\%), plastics and pharmaceuticals [4]. The main imported goods were fuel (20.06\% of imports), machinery (10.97\%), electrical equipment (10.97\%), vehicles (9.55\%), plastics and pharmaceuticals [4]. Due to the COVID-19 pandemic in 2020, trade volumes fell, exports of goods and services decreased by $4 \%$ compared to 2019 , and imports by $7 \%$ [6]. The IMF expects that the recovery in imports (+ $12.4 \%)$ will be stronger than the recovery in exports $(+5.5 \%)$ in 2021 [4]. Exports are affected by low prices for agricultural products, iron and steel, caused by low world demand.

Regarding trends in foreign trade, Ukraine seeks developing the trade relations with European Union member states and China. The EU and Ukraine have been provisionally applying their deep and comprehensive Free Trade Agreement (CCFTA) since January 2016. The EU's share of Ukraine's merchandise exports increased from $34.1 \%$ in 2015 to $41.4 \%$ in 2018. [6] . China has become Ukraine's main trading partner. In 2019, China accounted for $15.2 \%$ of Ukraine's imports [6]. In addition to the COVID-19 pandemic, foreign trade is also negatively affected by political issues.

As for Germany's foreign trade, it is the third largest importer and exporter in the world [4]. The country is currently the world's largest exporter of cars (just under 19\% of the world's total car exports) [6], but it also exports machinery, medicines and aircrafts. The main imports were also cars, petroleum oils, petroleum gases and medicines [6]. However, the outbreak of the COVID-19 pandemic disrupted international trade, also affecting the German market: according to IMF estimates, in 2020, German exports fell by $12 \%$ per year, imports also have similar trends (-8.4\%). It is expected that in 2021 both indicators will recover $(+9 \%$ and $+7.7 \%$ respectively) [4].

Germany's main trading partner is the European Union, which accounts for $68.2 \%$ of exports and $67.8 \%$ of imports [5]. For some countries, the main directions for exports were the United States (8.9\%), France (8\%), China (7.3\%), the Netherlands (6.2\%) and the United Kingdom (5.9\%); while imports came mainly from China (10\%), the Netherlands (7.9\%), the United States (6.6\%), France (6\%) and Poland (5.2\%) [5]. Germany continues to be the "most open" economy in the G7.

In 2019, Germany exported goods worth 1,489 billion dollars. US (a decrease of $4.5 \%$ over the same period last year), importing a total of 1234 billion dollars. USA (-3.9\%) [4]. Germany is a net importer of commercial services: in 2018, the country exported services worth $\$ 335$ billion. US, while imports were slightly higher - 362 billion dollars. [5]. However, the country's trade balance is structurally positive: in 2019, Germany's current account surplus amounted to $7.1 \%$ 
of GDP [7], which is the highest figure in the world (second place in nominal terms after China).

As for unemployment in Germany, it increased by $0.8 \%$ between February and July 2020 and totaled $6.4 \%$ (an increase of $1.4 \%$ compared to a record low reached in mid-2019) [ 4]. According to a GDP per capita of \$ 56,052, [4] Germany is one of the richest countries in the world. However, according to Destatis, about $17.4 \%$ of the country's population is at risk of poverty or social exclusion and this ratio is expected to increase after the COVID-19 crisis [5].

The analysis of the impact of COVID-19 on the economies of Ukraine and Germany shows that quarantine has almost stopped several sectors of the economy - retail, hotel and restaurant business, air transportation. The amount of budget revenues decreased. As a result of the quarantine, Ukrainian and German companies froze investments and production chains. It should be noted that the sectors where quarantine restrictions are eased, and which are related to consumer demand are recovering rapidly, especially retail trade and services.

Germany is among the top five countries in terms of funding of economic programs - 815.6 billion US dollars, or 20.2\% of GDP [8]. In April 2020, the Government of Ukraine decided to create a fund for UAH 66 billion to fight the coronavirus and took a number of social policy measures to mitigate the effects of quarantine [4].

Germany's well-known success in the fight against the COVID-19 pandemic is largely due to the existence of a special plan in case of such a situation - in particular, the state of emergency, adopted in 1968, and the Infectious Diseases Protection Act 2001, which regulates competencies of the federal government and regional authorities on epidemiological surveillance. In addition, the Robert Koch Institute centrally issues updated detailed recommendations for fighting coronavirus infection, which include both practical steps to protect the population and instructions for the health care system, which are followed by all medical institutions in the country.

The German government has introduced fines and forms of punishment for prosecuting quarantine violations, although legally they are based on a single federal law "On protection against infectious diseases." Maximum fines of up to 25 thousand euros or penalties up to prison terms are provided in case of infection of other citizens as a result of violation of quarantine [9]. In 15 federal states of Germany, the requirement of mandatory use of masks in public places has been introduced, for violation of which fines from 25 to 150 euros are imposed, depending on the region [9].

For the lack of masks in public places, the government of Ukraine imposes fines ranging from 170 to $250 \mathrm{UAH}$. In case of violation of the rules of quarantine and sanitary and hygienic norms a fine of 17 thousand to 170 thousand UAH isintroduced. In addition, the Verkhovna Rada in the Criminal Code increased the responsibility for violating sanitary rules and regulations, if such a violation led to the spread of the disease. It was decided to increase the fine for such actions from 1,700 UAH to 17-51,000 UAH. If previously the punishment in the form of arrest for up to 6 months was presupposed as well as restriction of freedom for up to 3 years, now the punishment may also include imprisonment for up to 3 years. The provision of imprisonment for a term of 5 to 8 years remains, if such actions have resulted in death or other serious consequences.

Let's analyze more thoroughly what measures were used by the governments of Ukraine and Germany to overcome the COVID-19 pandemic and stabilize the economic situation (tab. 3).

Table 3. Measures to overcome the COVID-19 pandemic and stabilize the economic situation in Ukraine and Germany

\begin{tabular}{|c|c|c|}
\hline № & Ukraine & Germany \\
\hline 1. & $\begin{array}{l}\text { In April } 2020 \text {, the government made a one-time } \\
\text { payment of UAH } 1,000 \text { to low-income pensioners } \\
\text { and introduced a total additional payment of UAH } \\
500 \text { to pensioners over the age of } 80 \text { (a total of } \\
\text { about } 1.5 \text { million people). }\end{array}$ & $\begin{array}{l}\text { Unemployment payments have been extended for three } \\
\text { months for those who stop receiving them in the period } \\
\text { from } 01.05 .2020 \text { to } 31.12 .2020 \text {. Simplified access for } \\
\text { receiving of basic income, especially for private } \\
\text { entrepreneurs and artists. Compensation is paid for } \\
\text { citizens who are unable to continue working due to } \\
\text { quarantine or in case of being infected with COVID-19. }\end{array}$ \\
\hline 2. & $\begin{array}{l}16 \text { billion UAH have been allocated for the health } \\
\text { care system, in particular to provide physicians with } \\
\text { personal protective equipment, to pay them higher } \\
\text { salaries, to purchase the necessary equipment for } \\
\text { hospitals, including respirators, as well as for the } \\
\text { construction, reconstruction and repair of reception } \\
\text { departments of health care support facilities. I'm in } \\
\text { hospital districts. In addition, parliament has adopted } \\
\text { state-funded health insurance, which applies in the } \\
\text { event of death or occupational disability related to } \\
\text { Covid-19. }\end{array}$ & $\begin{array}{l}100 \text { billion EUR have been allocated to recapitalize and } \\
\text { buy stakes in companies affected by the pandemic } \\
\text { through the Economic Stabilization Fund; } 3.1 \text { billion } \\
\text { EUR will be transferred annually for the period of } \\
2021-2024 \text { for additional investments in the private } \\
\text { sector; } 365.5 \text { billion EUR have been allocated to } \\
\text { expand the existing Business Guarantee Program under } \\
\text { the National Bank for Reconstruction (KfW) and } 100 \\
\text { billion EUR to refinance large debts to the } \\
\text { organization; } 400 \text { billion EUR have been allocated to } \\
\text { provide guarantees and maintain the liquidity of } \\
\text { companies under the Economic Stabilization Fund. }\end{array}$ \\
\hline 3. & $\begin{array}{l}\text { As an additional measure, the government provides } \\
\text { assistance to temporarily employed workers who } \\
\text { risk losing their jobs due to quarantine restrictions. } \\
\text { Between April and July, employers received } \\
\text { compensation for short-term employment of a total } \\
\text { of } 375 \text { thousand employees (employers receive this } \\
\text { support during the lockdown of their companies and } \\
\text { for one month, after which employees remain in the } \\
\text { company). In addition, the minimum amount of } \\
\text { unemployment benefits was increased from UAH }\end{array}$ & $\begin{array}{l}\text { Benefit payments have been increased: citizens whose } \\
\text { working hours have been reduced by } 50 \% \text { will be paid } \\
70 \% \text { of their fixed net remuneration }(77 \% \text { for workers } \\
\text { with children) starting from April } 2020 \text {, and } 80 \% \text { ( } 87 \% \\
\text { for workers with children) starting from July } 2020 \text {. } \\
\text { Employees were allowed to combine work (receive } \\
\text { additional earnings) without deducting benefits (a } \\
\text { similar measure applies to retirees). The period of } \\
\text { privileged conditions of assistance is extended from } 70 \\
\text { to } 115 \text { days (low fixed tax rate, etc.). The compensation }\end{array}$ \\
\hline
\end{tabular}




\begin{tabular}{|c|c|c|}
\hline & 1,630 to UAH 1,800 . & mechanism applies to temporary workers as well. \\
\hline 4. & $\begin{array}{l}\text { The government has allocated } 1 \text { billion UAH for } \\
\text { state support in the field of culture, tourism and } \\
\text { creative industries. } 475.8 \text { million UAH was also } \\
\text { allocated for the partial recovery of expenditures in } \\
\text { the field of physical culture and sports. }\end{array}$ & $\begin{array}{l}33.5 \text { billion EUR have been allocated in the form of tax } \\
\text { benefits and other reductions in tax revenues; } 500 \\
\text { billion EUR in tax deferrals, including } 70 \text { billion EUR } \\
\text { in direct corporate income tax deferrals, and } 430 \text { billion } \\
\text { EUR in indirect taxes and social security contributions. }\end{array}$ \\
\hline 5. & $\begin{array}{l}\text { To finance the unemployment fund - about } 7 \\
\text { billion, of which } 2.7 \text { billion is allocated for partial } \\
\text { unemployment benefits. Another } 1.2 \text { billion has } \\
\text { been allocated by the Ministry of Social Policy for } \\
\text { individual entrepreneurs who cannot work due to } \\
\text { quarantine restrictions and have children under the } \\
\text { age of } 10 \text {. Also, } 2.5 \text { billion is directed to additional } \\
\text { payments to servicemen, police and relevant } \\
\text { categories that ensure the livelihood of the } \\
\text { population. }\end{array}$ & $\begin{array}{l}50 \text { billion EUR in direct subsidies have been allocated } \\
\text { to private entrepreneurs and micro-enterprises (up to } \\
15,000 \text { EUR per company); } 10 \text { billion EUR in } \\
\text { additional compensation under the part-time work } \\
\text { program (Kurzarbeitergeld). }\end{array}$ \\
\hline 6. & $\begin{array}{l}\text { A forced moratorium on public services debt has } \\
\text { eased the state of those who have lost income as a } \\
\text { result of quarantine measures. The government has } \\
\text { also simplified access to housing and government } \\
\text { subsidies for energy, increasing the average value } \\
\text { used for energy consumption by } 50 \% \text {. This has led to } \\
\text { an increase in disbursements. It was also decided that } \\
\text { the registration of subsidies for the future heating } \\
\text { period will be applied automatically. }\end{array}$ & $\begin{array}{l}\text { A moratorium on evictions has been introduced. Lease } \\
\text { debts must be reimbursed no later than } 30.06 .2022 \text {. } \\
\text { Citizens have the right to defer payments for gas, } \\
\text { electricity, telephone. They cannot be disconnected } \\
\text { from the life support system. A number of measures } \\
\text { have been taken to reduce tax arrears: a moratorium on } \\
\text { the payment of tax arrears, and the termination of court } \\
\text { rulings on the seizure of property. }\end{array}$ \\
\hline 7. & $\begin{array}{l}\text { Of particular note is the expansion of the state } \\
\text { program 5-7-9 for "soft" loans, which was } \\
\text { introduced to help the economy through cheap } \\
\text { loans: the amount of loans was increased and the } \\
\text { estimated interest rates were reduced. In addition, } \\
\text { companies can get loans to cover current expenses } \\
\text { (so that they not only had to spend their capital on } \\
\text { them) and to pay out old loans on more favorable } \\
\text { terms. Thanks to this assistance, small and medium- } \\
\text { sized companies have been able to continue their } \\
\text { operations and save jobs. Another case was the } \\
\text { refinancing of loans issued by the NBU, which were } \\
\text { intended to ensure the smooth operation of banks } \\
\text { and loans to companies. Other important measures } \\
\text { are related to the digitalization of many services. }\end{array}$ & $\begin{array}{l}\text { Procedures for receiving child benefits for low-income } \\
\text { families have been simplified. Child benefit, which is } \\
\text { coming to an end, will be automatically extended for } \\
\text { six months without further revision. Citizens forced to } \\
\text { stay at home to care for a child due to school closure } \\
\text { are paid up to } 67 \% \text { of lost income, but not more than } \\
2016 \text { euros per month and for up to six weeks, single } \\
\text { parents - for up to } 20 \text { weeks; for children in key } \\
\text { industries, childcare is provided in kindergartens and } \\
\text { schools. Social support for teachers and students } \\
\text { includes the retention of federal education grants } \\
\text { (BAföG) even in cases where teaching in schools or } \\
\text { universities is suspended; about } 540 \text { social institutions } \\
\text { received additional funding to expand social assistance } \\
\text { to the needy. A one-time bonus of } 1,000 \text { EUR is } \\
\text { available for caregivers. }\end{array}$ \\
\hline 8. & $\begin{array}{l}\text { Most of the fund's money was spent on road } \\
\text { maintenance and construction ( } 35 \text { billion UAH) - } \\
\text { officially justified by the fact that it will boost the } \\
\text { country's economy and create jobs. }\end{array}$ & $\begin{array}{l}\text { The German government has allocated } 2 \text { billion euros } \\
\text { to expand funding for startups, new technology } \\
\text { companies and small businesses. }\end{array}$ \\
\hline
\end{tabular}

By studying Germany's experience in fighting COVID-19, Ukraine could implement certain measures to stabilize the country's economy, namely: 1) to promote payments to unemployed private entrepreneurs who lost their business due to the pandemic; 2) increase payments to citizens whose working hours have been reduced by $50 \%$ or more; 3 ) allocate subsidies for tourism enterprises (aviation, hotel and restaurant business) to prevent bankruptcy; 4) provide citizens with deferral of utility payments; 5) pay subsidies to citizens who are forced to stay at home to care for a child.

The Federal Ministry of Foreign Affairs notes that humanitarian aid is an integral part of Germany's foreign policy. The country has repeatedly donated both funding and humanitarian aid to other countries to help fight the spread and economic consequences of coronavirus infection.

In early March, Germany, together with France and the United Kingdom, through the WHO and other UN organizations, provided Iran with 5 million euros in aid to fight the COVID-19 epidemic. Under the European Solidarity Program, Germany provided 7.5 tons of humanitarian aid to Italy; sent mechanical ventilation to Spain and France. In addition to direct financial and humanitarian assistance, Germany provides support in the treatment of seriously ill citizens of other countries.

Germany was one of the organizers of the largest international donor online conference under the auspices of the WHO and the European Commission on 04.05.2020, on the first day of which 7.4 billion euros were raised for the development of a vaccine against coronavirus and other pandemic medicine. Germany itself has pledged more than 500 million euros [8].

In addition, in the context of international humanitarian aid, the activity of German non-governmental organization Bread for the World (Brot für die Welt), which provides assistance to low-income citizens in more than 90 countries, as well as experts from the Rapid Response Group (SEEG), is notable while providing advice and information support to strengthen local health systems [8]. 
Unfortunately, Ukraine acts as a recipient of humanitarian and financial assistance. The International Atomic Energy Agency (IAEA) has sent more than 2 million UAH in humanitarian aid to Ukraine [8]. On April 8, 2020, the European Union decided to provide financial support to Ukraine in the fight against COVID-19 in the amount of about 190 million euros. Due to the economic crisis caused by the coronavirus disease pandemic, the European Commission has allocated macro-financial assistance in the amount of 1.2 billion euros, which was aimed at maintaining the economic stability and balance of payments of our country [8].

According to the Ministry of Foreign Affairs, the largest donor of Ukraine in terms of financial assistance is the United States - initially they allocated 17.3 million dollars. emergency medical care to Ukraine. In October, this amount was increased to \$ 19 million, and another \$ 5.2 million was humanitarian aid from the State Department "to support the most vulnerable during the pandemic" [8].

The analysis of the economic consequences of the coronavirus suggests that the rapid spread of the COVID-19 pandemic has become a global challenge that requires a rapid search for effective countermeasures. The German government has introduced a number of initiatives to mitigate the effects of the pandemic with economic instruments. The focus of such initiatives is on preserving the integrity of the single market, providing support to German citizens and businesses, and identifying rapid response measures to maintain the stability and solidarity of EU Member States. The first anti-crisis steps of the German government in the field of economy deserve attention from the central executive bodies of Ukraine.

Conclusions. Unlike many countries around the world, Germany not only objectively approached the COVID-19 pandemic being better prepared in organizational, economic and social terms, but also without delay took comprehensive response measures, preventing the escalation of the epidemiological and economic situation. Thanks to the high potential of the health care system and the appropriate steps of the government, Germany was able to successfully cope with a large number of infected patients, as well as stabilize the economy and develop a successful "crisis package". The country's strong economy has allowed the government to take an unprecedented package of measures to support business activity and social assistance to citizens, which has mitigated the economic consequences of the spread of the infection. Although further recovery will be associated with the state and prospects of the global economy.

The depth and seriousness of the economic problems which Ukraine faces in the context of the COVID-19 pandemic and the global economic crisis require a more comprehensive and broad approach. Therefore, taking into account the experience of Germany, Ukraine must develop its "anti-crisis package", which should be seen as a long-term investment not only in overcoming the economic consequences of COVID-19, but also in saving post-crisis recovery and development of the entire Ukrainian economy.

Thus, the COVID-19 pandemic could lead to global changes in the international economies of Ukraine and Germany. However, there is not enough material for profound forecasts, so the analysis of economies in general needs further research.

\section{References.}

1. The official site of Ilo (2020), "ILO: COVID-19 causes devastating losses in working hours and employment", available at: https://www.ilo.org/global/about-the-ilo/newsroom/news/WCMS_740893/lang--en/index.htm (Accessed 07 April 2020).

2. Todorov, I.Y. and Todorov, N.Y. (2020), "The impact of the COVID-19 pandemic on international relations", Geopolitics of Ukraine: history and modern times, vol. 1(24), pp. 1-9.

3. Boiarynova , K. O. Dergachova, V. V. Kravchenko, M. O. and Kopishynska K. O. (2020), "Analyzing Forecasts of the Influence of the Coronavirus Pandemic on the Economy of Ukraine and the Neighboring Countries", Business Inform, vol. 7, pp. 1-10.

4. The official site of WTTC (2020), "Coronavirus puts up to 50 million Travel \& Tourism jobs at risk", available at:https://wttc.org/Portals/0/Documents/Press\%20Releases/Coronavirus\%20puts\%20up\%20to\%2050\%20million\%20Trave 1\%20and\%20Tourism\%20jobs\%20at\%20risk\%20says\%20WTTC.pdf?ver=2020-10-26-143855-200 (Accessed 13 March 2020). available at:https://www.destatis.de/EN/Themes/Society-Environment/Income-Consumption-Living

5. The official site of Statistisches Bundesamt Deutschland (2021), "At-risk-of-poverty or social exclusion", Conditions/_graphics/_Interactive/living-conditions-at-risk-of-poverty-social-exclusion.html.

6. The official site of IATA (2020), "Deeper Revenue Hit from COVID-19", available at: https://www.iata.org/en/pressroom/pr/2020-03-24-01/ (Accessed 24 March 2020).

7. The official site of IMF (2021), International Monetary Fund, available at: https://www.imf.org/en.

8. The official site of World Bank (2021), World Bank Group - International Development, Poverty, \& Sustainability, available at: https://www.worldbank.org/en/home.

9. The official site of WTO (2021), World Trade Organization - Global trade, available at: https://www.wto.org/.

10. The official site of ITC (2021), International Trade Center, available at: https://www.intracen.org/.

11. The official site of BMWi (2021), Bundesministerium für Wirtschaft und Energie, available at: https://www.bmwi.de/.

12. The official site of Der Tagesspiegel (2020), "Diese Bußgelder drohen bei Verstößen gegen Berlins CoronaVerordnung", available at: https://www.tagesspiegel.de/berlin/zwischen-10-euro-und-25-000-euro-diese-bussgelderdrohen-bei-verstoessen-gegen-berlins-corona-verordnung/25711362.html (Accessed 03 April 2020). 